\title{
ASSESSING THE LAND AND CROP SUITABILITY AS A BASIS FOR SELECTION OF AN OPTIMAL CROP PATTERN AND CROP ROTATION MODEL TO BE APPLIED TO DEEP RESIDUAL SOILS OF DONGOLA REGION (NORTH SUDAN-DONGOL)
}

\section{ISTRAŽIVANJE POGODNOSTI ZEMLJŠTA I BILJNIH VRSTA, KAO OSNOVE ZA IZBOR OPTIMALNE STRUKTURE I MODELA ROTACIJE USEVA, SA PRIMENOM NA DUBOKA REZIDUALNA ZEMLJIŠTA REGIONA DONOGOLA (SEVERNI SUDAN-DONGOL)}

\author{
Žeželj Branislav ${ }^{1}$, Hojka Zdravko \\ ${ }^{1}$ Megatrend University, Faculty for Bio farming, M. Tita no.39, 24300 Backa Topola, Serbia \\ 2"Meling" Ltd. Comp. Owner-Manager, Marsala Tolbuhina no. 13, 11080, Belgrade-Zemun, Serbia \\ e-mail: melingzezelj@gmail.com
}

\section{SUMMARY}

The aim of the study was to scan land suitability for Agriculture i.e. land utilization types which is, partly described by the FAO (1976), the fitness of a specific tract of land for a specified kind of land use under a stated system of land management, but mainly and fulfilled by the results of the subjective study.

There are two specific objectives: Soil

I. Soil survey: soils characterization - soils classification according to the USA

Taxonomy - soils database (Profiles and routine observations with Excel) - soils mapping (scale 1:25,000).

II. Land evaluation: physical suitability of the soils of the project area for irrigated agriculture according to Sys et. al. (1991) for a number of selected crops, commonly grown in the surrounding areas.

The obtained field and laboratory investigation and results have introduced and then evaluated a three main soil groups (Typic/Litic Torriorthens, Litic Haplocamids and Typic Haplocamids). Aiming the most adequate cropping pattern and crop rotation models of the North Sudan land areas, based on detailed "Land and Crop suitability models optimization".

By the use of these models, a different Farms, Vegetable and Orchards-Fruits crop varieties, have been evaluated and finally chosen and presented as a general cropping management use, within the sustainable and integrated Agriculture production.

Key words: Land evaluation, crop suitability, land suitability, Residual soils, land reclamation, salt leaching. 


\section{INTRODUCTION}

As a first step towards assessing the land suitability of Dongola Experiential and Training Fields Areas, at Northern State, Sudan survey of the Study area have been conducted during 2018 by Orgamed Farms Company Ltd. (leaded by the study author), with the help in field and laboratory works by Department of Soil \& Environment Sciences, Faculty of Agriculture, Sudan University for Science and Technology University.

The experimental field is the part of "Berlin Agriculture Project and is situated on the eastern bank of the River Nile approximately $60 \mathrm{~km}$ from Dongla along DonglaKreima highway (Fig.1.). The long axis lies in East to West direction $(\approx 4 \mathrm{~km})$. Figure 1 . Depicts the location of the study area (2,000 fedans).

The aim of the study is to scan land suitability for Agriculture i.e. land utilization types which is, as described by the FAO (1976), the fitness of a specific tract of land for a specified kind of land use under a stated system of land management.

There are thee specific objectives:

III. Soil survey: soils characterization - soils classification according to the USA Soil (FAO, 1976).

IV. Taxonomy - soils database (Profiles and routine observations with Excel) - soils mapping (scale 1:25,000).

V. Land evaluation: physical suitability of the soils of the project area for irrigated agriculture for a number of selected crops, commonly grown in the project area and surrounding areas (Allison, L.E., 1956).

According to the study area falls in a desert climate-summer rains and cool winters (Van der Kevie, 1976). Table 2.1 shows the meteorological data of Kareima area sixty km to the east of the study area. Mean annual temperature is $29.1^{\circ} \mathrm{C}$. Average maximum temperatures in the hottest months (April - June) are 39.0 to $43.3^{\circ} \mathrm{C}$ while the minimum temperature for the same period is $21.3^{\circ} \mathrm{C}$ to $26.6^{\circ} \mathrm{C}$. The minimum temperature during the winter ( $\mathrm{Dec}-\mathrm{Feb}$ ) is $13.8^{\circ} \mathrm{C}$ to $12.2^{\circ} \mathrm{C}$. The relative humidity fluctuates during the day (GMT) and during the year (seasons). The mean annual relative humidity ranges between 29-22\% (Jan to Feb), 17-15\% (March to June) and 24-31\% (July to December).

The average annual rainfall is about $25.9 \mathrm{~mm}$ falling mainly in July and August with very low amounts in September. The rainfall is erratic in quantity, intensity and distribution. The area falls under the effect of northeasterly winds in October through May and southwesterly winds as from late June through October. The high temperatures coupled with strong solar radiation result in values of potential evapotranspiration exceeding by far the rainfall almost throughout the year, except in August (Table 1.; Fig. 2.), a phenomenon which is not unexpected for a desert climate which typifies the study area. 


\section{Table 1. Climatological normal (1941-2003) of Kareima Station}

\begin{tabular}{|l|l|l|l|l|l|l|}
\hline \multicolumn{1}{|c|}{ Months } & Jan & Feb & Mar & Apr & May & June \\
\hline Memp. ${ }^{\circ} \mathrm{C}$ & 20.3 & 22.0 & 25.8 & 30.1 & 33.7 & 34.9 \\
\hline Mean Max & 28.4 & 30.5 & 34.6 & 39.0 & 42.2 & 43.3 \\
\hline Mean Min & 12.2 & 13.5 & 17.1 & 21.3 & 25.2 & 26.6 \\
\hline Av. annual R F(mm) & 0.0 & 0.0 & 0.0 & 0.0 & 0.6 & 0.0 \\
\hline Evap. Piche (mm) & 5.8 & 7.1 & 8.5 & 9.5 & 10.2 & 9.7 \\
\hline Mean R. H. (\%) & 29 & 22 & 17 & 15 & 15 & 15 \\
\hline $\begin{array}{l}\text { Wind speed and } \\
\text { Direction }\end{array}$ & $247 \mathrm{~N}$ & $275 \mathrm{~N}$ & $276 \mathrm{~N}$ & $262 \mathrm{~N}$ & $260 \mathrm{~N}$ & $232 \mathrm{~N}$ \\
\hline
\end{tabular}

Table 1. cont. Climatological normal (1941-2003) of Kareima Station

\begin{tabular}{|l|l|l|l|l|l|l|l|}
\hline Temp. ${ }^{\circ}$ Months & July & Aug & Sep & Oct & Nov & Dec & Annual \\
\hline Mean & 34.5 & 34.3 & 34.4 & 31.7 & 26.0 & 21.6 & 29.1 \\
\hline Mean Max & 42.0 & 41.4 & 41.9 & 39.4 & 33.6 & 29.4 & 37.2 \\
\hline Mean Min & 27.0 & 27.2 & 27.0 & 24.1 & 18.4 & 13.8 & 21.1 \\
\hline $\begin{array}{l}\text { Av. annual R } \\
\text { F(mm) }\end{array}$ & 8.0 & 13.9 & 2.8 & 0.6 & 0.0 & 0.0 & 25.9 \\
\hline Evap. Piche (mm) & 8.9 & 8.6 & 8.7 & 8.1 & 6.8 & 5.8 & 2.97 \\
\hline Mean R. H. (\%) & 24 & 28 & 21 & 22 & 27 & 31 & 22 \\
\hline $\begin{array}{l}\text { Wind speed and } \\
\text { Direction }\end{array}$ & $205 \mathrm{~N}$ & $206 \mathrm{~N}$ & $219 \mathrm{~N}$ & $234 \mathrm{~N}$ & $249 \mathrm{~N}$ & $249 \mathrm{~N}$ & $243 \mathrm{~N}$ \\
\hline
\end{tabular}

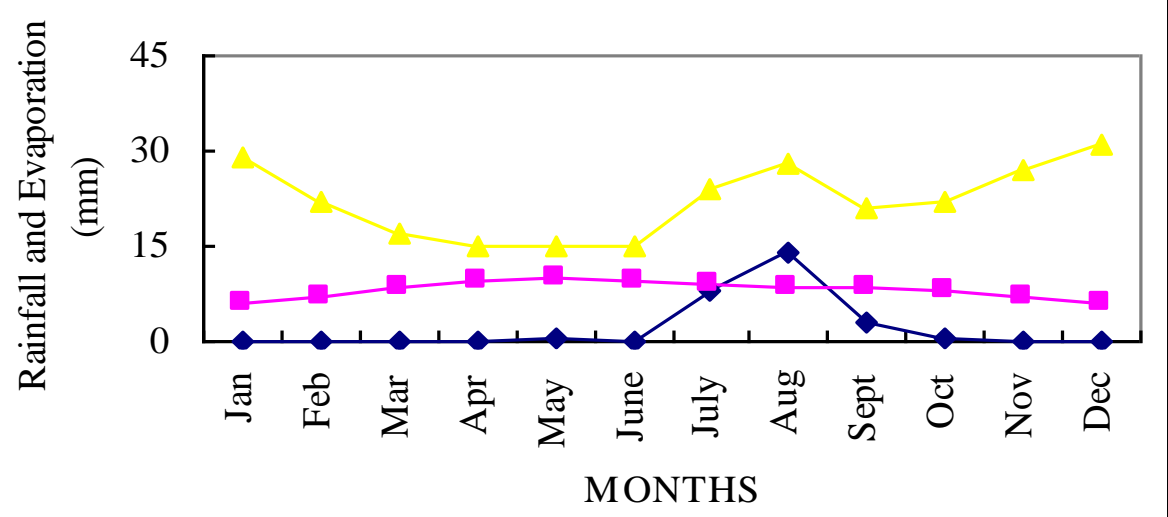

$\multimap$ Rainfall $\longrightarrow$ Evaporation $\longrightarrow$ R.H.

Fig. 2. Rainfall, evaporation and relative humidity of Kareima area during the period $1941-2003$ 
The main geological formations in the area are Basement complex and Nubian Sandstone formation. Basement complex rocks outcrop only at small batches. The study area can be divided into the following physiographic units:

- Slightly elevated undulated areas: these are flat/concave plains. They are covered with sand sheets of varying depths and underlain by fluviatile deposits- siltstone, mudstone and sandstone (Geological map of Sudan, 1981).

- Abandoned wades and chord channels: these are flat plains with alluvial origin covered invariably with thin sheets of sands.

- Galaa: these are elevated convex areas consisting of gravel boulders stones and rock fragments. They seem to have resulted from the physical weathering of the parent material followed by deflation of the fine material leaving gravels and boulders behind (Boul, S. Et.all., 1956).

\section{MATERIALS AND METHODS}

This stage started by entering the coordinates of the boundaries of the study area into a satellite image. Then a square grid was set up to represent the location of the auger sites and/or representative soil profiles. The grid was aligned so that in the field the auger sites were $250 \mathrm{~m}$ apart (i.e. scale 1:25,000 and density of observation of 1 observation $/ \mathrm{cm}^{2}$ on the map) in all directions. At this density of observation the total number of check sites (auger sites + representative) in the field was 107 sites.

The locations of the auger sites, within the boundaries of the study area, were given serial numbers and their coordinates were recorded printouts of this grid were reproduced to be used for navigation and location of the check sites by the different auger description and sampling groups in the field.

The grid was superimposed on the satellite image (False colors composite (FCC) composed of three bands) and the image plus the grid were color-printed in A0 sheets.

The following materials were consulted or used:

- Coordinates of the study areas.

- False colors composite (FCC) composed of three bands from the wavelength of the electromagnetic spectrum acquired by Enhanced Thematic Mapper Plus (ETM+).

- Hardware and Software:PC Intel Core ${ }^{\mathrm{TM}}$ Duo 80 GB.HD, $2.32 \mathrm{MHz}$ speed and 256 RAM, Scanner Genius Color page-HR5 30-Bit optical resolution 600X1200 DPI SCSI, Color printer HP Desk jet 7000 series, Digital Cameras, Erdas Imagine 8.5., ArcGis, Microsoft Excel 2007, Microsoft Word 2007, GARMIN eTrex Venture HC GPS receiver.

Besides the ougers, 9 soil profiles at the above-mentioned density of observation. Table 2 gives a summary of the scope of the field work in the study area.

Table 2. The scope of the targeted and achieved field work

\section{Item}

Area (feddans)

Number of auger sites

Number of soil samples from auger sites

Number of representative soil profiles

Number of soil samples from representative soil profiles
Targeted

$\approx 2000$

107

321

9

27
Achieved $\approx 1650$

107

310 


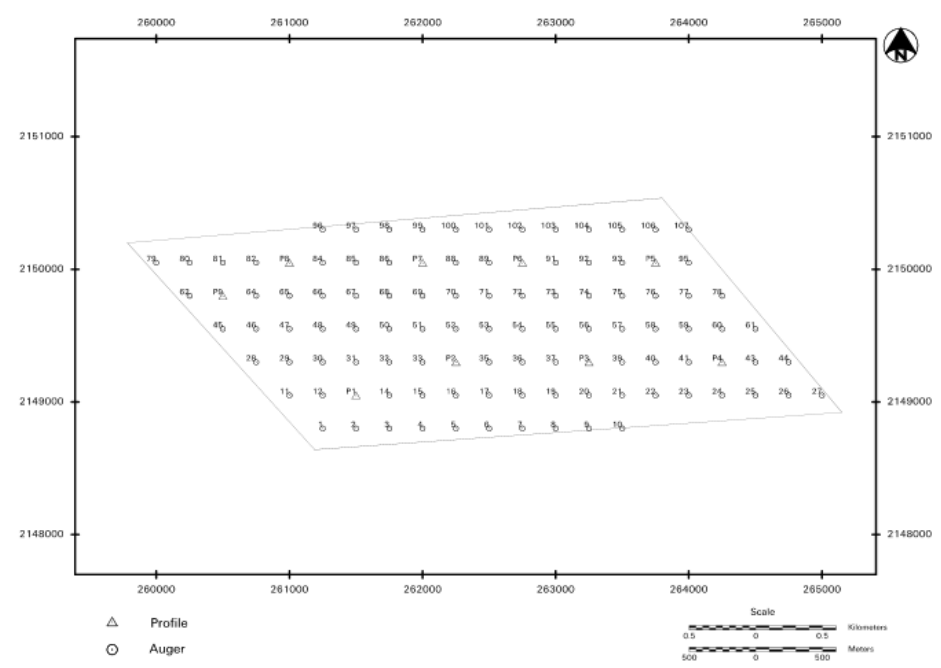

Figure 3. The grid showing the location of the auger and representative soil profile sites

The tentative locations of the soil profiles were again checked on the basis of a quick tour in the field made one day before each group of soil profiles were to be dug. Representative soil profiles were later selected from among these soil profiles to determine crop suitability for different mapping units. At each soil profile site a pit $(1 \mathrm{x}$ $1 \mathrm{x} 1.5 \mathrm{~m}$ ) was manually dug. Each horizon or layer was photographed. Each profile was then tentatively classified down to the subgroup level or phases of sub groups according Keys to Soil Taxonomy (USDA, 2010) on the bases of its morphological properties (FAO, 1985).

A total of 300 auger samples and 26 soil profile sample were analyzed. The analysis run and methodology adopted in the auger and soil profile samples are shown in Tables 3. and 4. respectively.

Table 3. Soil analysis and analytical methods for auger samples

\section{- $\quad$ Soil pH}

Determined in the saturated soil paste. The $\mathrm{pH}$ was read by a glass/calomel electrode (concentrated KCL) system ( Model Superfit ${ }^{\mathrm{TM}}$ Digital $\mathrm{pH}$ Meter).

- $\quad$ Electrical Conductivity (ECe) $\mathrm{dS} / \mathrm{m}$ at $25^{\circ} \mathrm{C}$

Determined in saturation extract. The ECe of the suspension was read using a digital EC conductivity meter (Model Jenway 4510 Conductivity Meter)

- $\quad$ Sodium Adsorption Ratio (SAR)

$\mathrm{SAR}=\mathrm{Na} / \sqrt{(\mathrm{Ca}+\mathrm{Mg}) / 2}$, soluble $\mathrm{Na}, \mathrm{Ca}$ and $\mathrm{Mg}$ substituted in this equation are in Mmole+ / $\mathrm{L}$

- $\quad$ Soluble $\mathrm{Na}$ and $\mathrm{K}$ were determined using flame photometer, $\mathrm{Ca}$ and $\mathrm{Mg}$ by titration with EDTA. 

pattern and crop rotation model to be applied to deep residual soils of Dongola region (north SudanDongol). Savr. polj. tehn. 45(4): 17/-184.

\section{Table 4. Soil analysis and analytical methods for soil profile samples}

\section{- $\quad$ Particle Size Analysis}

All results refer to oven dry soil. The soil was treated with $\mathrm{HCl}$ to destroy calcium carbonate, washed to remove soluble salts and dispersed chemically with calgon and mechanically with a dispersion machine. The pipette method was used to determine the clay fraction and wet sieving for the separation of the sand fraction. The silt fraction was obtained by subtraction from $100 \%$. Sand fractionation was done using the appropriate set of sieves.

\section{- $\quad$ Soil Textural Class}

The USDA textural triangle was used to determine the textural class of the soils

\section{- \%Organic Carbon (OC),}

Determined by the modified Walkly - Black method. The sample was oxidized with potassium dichromate + sulphuric acid and the excess potassium dichromate that was back titrated with ferrous ammonium sulphate. Recovery factor was 0.77

\section{- $\quad$ Total Nitrogen $(\mathbf{N}), \%$}

Modified Micro Kjeldahl method. Pre-moistened soil was digested with concentrated sulphuric acid Distillate, using ammonium hydroxide to liberate ammonia, was received in $2 \%$ boric acid and titrated using $0.01 \mathrm{M}$ sulphuric acid

\section{- $\quad$ Available phosphorus (P), ppm}

Determined by Olsen sodium bicarbonate extraction method.

\section{- $\quad$ Soil pH}

Determined in the saturated soil paste. The $\mathrm{pH}$ was read by a glass/calomel electrode (concentrated KCL) system (Model Superfit ${ }^{\mathrm{TM}}$ Digital pH Meter).

\section{- $\quad$ Calcium Carbonate (CaCO3),}

Determined by titration. The soil was boiled with 1N HCL. Excess acid was titrated versus $1 \mathrm{~N} \mathrm{NaOH}$ using phenolphthalein indicator.

\section{- $\quad$ Electrical Conductivity (ECe) $\mathrm{dS} / \mathrm{m}$ at $25^{\circ} \mathrm{C}$}

Saturated soil paste was prepared by adding a known weight of soil to a known quantity of water to paste consistency. Saturation extract was sucked off using a vacuum pump. ECe of the saturation extract was read with a conductivity meter ((Model Jenway 4510 Conductivity Meter).

\section{- $\quad$ Soluble Cations, mmol+/l}

Soluble anions and cations were determined in mmol+/L. Soluble Na was determined in the saturation extract by the flame-photometer. $\mathrm{Ca}$ and $\mathrm{Mg}$ were determined by titration with EDTA. Soluble K, which is usually cited as traces or in negligible values, was determined using the flame-photometer.

\section{- $\quad$ Sodium Adsorption Ratio (SAR)}

$\mathrm{SAR}=\mathrm{Na} / \sqrt{(\mathrm{Ca}+\mathrm{Mg}) / 2}$. Soluble $\mathrm{Na}, \mathrm{Ca}$ and $\mathrm{Mg}$ substituted in the equation, are in Mmol+./litre. 


\section{RESULTS AND DISCUSSIONS}

Land form units identified in the study area include the following:

1. Slightly elevated undulated areas: these are flat plains between abandoned wades and chores. They are covered with sand sheets of variable depths. In some places they were underlain by fluviatile deposits (siltstone, mudstone and sandstone).

2. Abandoned wades and chores channels: these are seasonal wades and chores, in this area are small seasonal water courses i.e. rills, they transected the land and constitute a very complex structure.

3. Galaa: These are elevated convex areas consisting of gravel, boulders and rock fragments. They seem to have resulted from physical weathering of the parent materials followed by deflation of the fine materials which left gravel and boulders behind.

The soils of the area in so far as their origin is concerned can be divided into the following:

1. Sedentary (residual) soils: these soils occupy partially elevated sites. They seem to have being affected by chemical weathering during a former more wet period than the present climate. They are medium textured soils of grayish and dark grayish color.

2. Transported soils: These are soils which have resulted from weathering products transported into the area either by wind or water (colluvial and fluvial processes).

The soils of the study area were classified according to the Soil Taxonomy (Keys to Soil Taxonomy, 2010) from the order down to the subgroup level. The soils were classified mainly on the effect of the soil forming factors and processes on morphology of the soils as reflected in the field. In some cases a saline, sodic, shallow or gravel phase was superimposed on the subgroup level.

The differentiating (diagnostic) characteristics used at the different categorical levels in class included the following:

- Presence or absence of major diagnostic horizons i.e. those which are indicative to the leading soil forming processes that dominated the course of soil formation (ORDERS).

- Presence or absence of properties associated with wetness, soil moisture regime, and major parent material that all reflect genetic homogeneity (SUBORDERS).

- Kind, arrangement and degree of expression of soil horizons, with emphasis on the upper sequm; moisture regime (GREAT GROUPS).

- Expression of central concepts of the great group, deviation (within the great group) from the central concept of the great group or intergradations to other great groups, suborders or orders (SUBGROUPS).

Soil properties and characteristics that were found to be of special use in classifying the soils of the area included:

Lack of horizonation (lack of pedogenic horizons) and presence of transitory properties such as sedimentation layers. Presence of sub-surface diagnostic horizons e.g. Cambic horizon. Degree of horizon differentiation within the soil profile. Presence or absence, nature and distribution of calcium carbonates. Soil depth. Soil color. Presence of gravels. Levels of ECe (salinity) and SAR (sodicity). 
Žeželj B. i sar. (2019): Assessing the land and crop suitability as a basis for selection of an optimal crop pattern and crop rotation model to be applied to deep residual soils of Dongola region (north SudanDongol). Savr. polj. tehn. 45(4): 171-184.

Table 5. Classification of the area down to the Subgroup (SG) level

\begin{tabular}{|l|l|l|l|}
\hline $\begin{array}{l}\text { Unit } \\
\text { No. }\end{array}$ & Classification (GG) & Phase & Profile No. \\
\hline 2 & Typic/lithic Torriorthents & & 2 \\
\hline 7 & Typic Haplocambids & Gravelly reddish phase & 1,3 \\
\hline 8 & Typic Haplocambids & Greyish reddish phase & $4,5,6,7,8,9$ \\
\hline
\end{tabular}

Soil units are areas of consistent soils or soil patterns. They are either simple units (consociations) dominated by one profile class, or compound units (association or complex) which are dominated by more than one profile class. All the mapping units delineated in the study area are consociations at the sub-group level. Table 6 presents a brief description and classification of the different mapping units.

Table 6. Brief description and classification of the different mapping unit

\begin{tabular}{|c|l|l|}
\hline 1 & $\begin{array}{l}\text { Shallow soils with no horizon differentiation confined } \\
\text { to the western and northern peripheries of the project in } \\
\text { addition to scatter pockets in the central part of the } \\
\text { project. They are covered by superficial gravel and } \\
\text { sand, they are sand clay loam and non-saline and non- } \\
\text { sodic. }\end{array}$ & Lithic Torriorthents, \\
\hline 2 & $\begin{array}{l}\text { Deep residual soils with a cambic horizon scattered as } \\
\text { pockets in south and north parts. They are non } \\
\text { cracking, non-saline, non-sodic, calcareous sandy clay } \\
\text { loam with reddish color. }\end{array}$ & $\begin{array}{c}\text { Typic Haplocambids } \\
\text { (Gravelly reddish) }\end{array}$ \\
\hline 3 & $\begin{array}{l}\text { Deep residual soils with a cambic horizon covered the } \\
\text { rest the project area and extended on the middle of the } \\
\text { survey area. They are non-cracking, non-saline, non- } \\
\text { sodic, calcareous sandy clay loam with reddish/grayish } \\
\text { color. }\end{array}$ & $\begin{array}{c}\text { Typic Halpocambids } \\
\text { (Greyish reddish) }\end{array}$ \\
\hline
\end{tabular}

The class limits of the soil properties used in the description of the individual mapping units are presented in Table 7.

Table 7. Class limits of the soil properties

\begin{tabular}{|l|l|}
\hline \multicolumn{2}{|l|}{$\mathbf{p H}\left(\mathbf{H}_{2} \mathbf{O}\right)$ (top soil ) } \\
\hline class & values \\
\hline NE neutral & $6.6-7.5$ \\
\hline AL alkaline & $7.5-8$ \\
\hline MA m. alkaline & $8-9$ \\
\hline & \\
\hline VA v. alkaline & $>9$ \\
\hline & \\
\hline
\end{tabular}




\begin{tabular}{|l|l|l|l|}
\hline \multicolumn{2}{|l|}{ Sodicity } & Salinity \\
\hline class & $($ SAR $)$ & Class & $\begin{array}{l}\text { (EC) } \\
(\mathrm{dS} / \mathrm{m})\end{array}$ \\
\hline NSOD Non-sodic & $<13$ & NS Non-saline & $<4$ \\
\hline SSOD Slightly sodic & $13-23$ & SS Slightly saline & $4-8$ \\
\hline SOD Sodic & $23-33$ & MS Moderately saline & $8-12$ \\
\hline STSOD Strongly sodic & $33-48$ & S Saline & $12-16$ \\
\hline VSTSOD Very strongly sodic & $>48$ & VS Very saline & $16-32$ \\
\hline & ES Extremely saline & $>32$ \\
\hline
\end{tabular}

\begin{tabular}{|l|l|l|l|}
\hline \multicolumn{2}{|l|}{ Organic Carbon (topsoil) } & Calcium Carbonate (topsoil) \\
\hline class & values (\%) & class & values (\%) \\
\hline VL very low & $<0.4$ & N very low & $<5$ \\
\hline LO low & $0.4-0.8$ & S low & $5-10$ \\
\hline ME medium & $0.8-1.2$ & M moderate & $10-20$ \\
\hline HI high & $>1.2$ & H high & $20-35$ \\
\hline \multicolumn{2}{|l}{} & V very high & $>35$ \\
\hline
\end{tabular}

\begin{tabular}{|c|c|c|c|c|c|}
\hline \multicolumn{6}{|l|}{ Texture } \\
\hline \multirow{2}{*}{ S sandy } & $\mathrm{S}$ & Sand & \multirow{2}{*}{ Si silty } & $\mathrm{Si}$ & Silt \\
\hline & & Loamy Sand & & SiL & Silty Loam \\
\hline \multirow{4}{*}{ L loamy } & & Loam & \multirow[t]{2}{*}{ SiC silty clayey } & $\mathrm{SiCL}$ & Silty Clay Loam \\
\hline & SL & Sandy Loam & & $\mathrm{SiC}$ & Silty Clay \\
\hline & SCL & Sandy Clay Loam & \multirow{2}{*}{ C clayey } & $\mathrm{SC}$ & Sandy Clay \\
\hline & $\mathrm{CL}$ & Clay Loam & & $\mathrm{C}$ & Clay \\
\hline
\end{tabular}

The characteristics and properties of these taxonomic units are summarized below:

\section{Lithic Torriorthents}

\begin{tabular}{|c|c|c|c|c|c|c|l|l|l|}
\hline $\begin{array}{c}\text { Profile } \\
\text { No. }\end{array}$ & Depth & SAR & SO4 & $\begin{array}{c}\mathrm{HCO} \\
3\end{array}$ & $\mathrm{Cl}$ & $\begin{array}{c}\mathrm{CaCO} \\
3\end{array}$ & $\mathrm{P}$ & $\mathrm{N}$ & O.C \\
\hline $\mathrm{cm}$ & & $\begin{array}{c}\mathrm{meq} / \\
\mathrm{m}\end{array}$ & $\begin{array}{c}\mathrm{meq} / \\
1\end{array}$ & $\mathrm{meq} / 1$ & $\%$ & $\mathrm{ppm}$ & $\%$ & $\%$ \\
\hline & $0-30$ & 0.40 & 1.01 & 6.0 & 22.0 & 3.9 & 1.5 & 0.42 & 0.10 \\
\hline & $30-65$ & 2.04 & $\begin{array}{c}34.1 \\
6\end{array}$ & 4.0 & 60.0 & 4.9 & & & \\
\hline & $\begin{array}{c}\text { averag } \\
\mathrm{e}\end{array}$ & 1.22 & $\begin{array}{c}17.5 \\
9\end{array}$ & 5.00 & 41.00 & 4.37 & 1.50 & 0.42 & 0.10 \\
\hline
\end{tabular}


Žeželj B. i sar. (2019): Assessing the land and crop suitability as a basis for selection of an optimal crop pattern and crop rotation model to be applied to deep residual soils of Dongola region (north SudanDongol). Savr. polj. tehn. 45(4): 17/-184.

\begin{tabular}{|c|c|c|c|c|c|l|}
\hline $\begin{array}{c}\text { Profile } \\
\text { No. }\end{array}$ & Depth & Caly & Silt & Sand & Gravel & \multicolumn{1}{|c|}{ texture class } \\
\hline & $\mathrm{cm}$ & $\%$ & $\%$ & $\%$ & $\%$ & \\
\hline P2 & $0-30$ & 20.1 & 8.4 & 71.5 & 28.9 & sandy clay loam \\
\hline & & & & & & \\
\hline & $30-65$ & 12.6 & 13.4 & 74.0 & 44.43 & sandy loam \\
\hline & average & 16.33 & 10.93 & 72.74 & 36.71 & \\
\hline
\end{tabular}

\section{Litic Haplocambids}

\begin{tabular}{|l|c|c|c|c|c|c|c|c|}
\hline Profile No. & Depth & SAR & SO4 & HCO3 & Cl & CaCO3 & P & N \\
\hline & $\mathrm{cm}$ & & $\mathrm{meq} / \mathrm{l}$ & $\mathrm{meq} / \mathrm{l}$ & $\mathrm{meq} / \mathrm{l}$ & $\%$ & $\mathrm{ppm}$ & $\%$ \\
\hline $\mathrm{p} 1$ & $0-40$ & 1.00 & 25.12 & 5.00 & 30.00 & 5.04 & 1.70 & 0.42 \\
\hline & $40-70$ & 1.72 & 264.70 & 5.00 & 370.00 & 4.95 & & \\
\hline & $70+$ & 3.25 & 194.10 & 4.00 & 270.00 & 4.05 & & \\
\hline
\end{tabular}

\begin{tabular}{|l|c|c|c|c|c|c|l|}
\hline Profile No. & Depth & O.C & Clay & Silt & Sand & Gravel & Texture class \\
\hline & $\mathrm{cm}$ & $\%$ & $\%$ & $\%$ & $\%$ & $\%$ & \\
\hline $\mathrm{p} 1$ & $0-40$ & 0.03 & 20.09 & 15.94 & 63.97 & 43.31 & sandy clay loam \\
\hline & $40-70$ & & 32.62 & 8.42 & 58.96 & & sandy clay loam \\
\hline & $70+$ & & 30.12 & 15.94 & 53.94 & & sandy clay loam \\
\hline & $86+$ & & 17.58 & 20.95 & 61.46 & & sandy loam \\
\hline
\end{tabular}

Typic Haplocambids (Greyish reddish)

\begin{tabular}{|c|c|c|c|c|c|c|c|c|}
\hline Profile No. & Depth & $\mathrm{SP} \%$ & $\mathrm{pH}$ & $\mathrm{EC} \mathrm{e}$ & $\mathrm{Ca}+\mathrm{Mg}$ & $\mathrm{Ca}$ & $\mathrm{Na}$ & $\mathrm{K}$ \\
\hline & $\mathrm{cm}$ & $\%$ & & $\mathrm{dS} / \mathrm{m}$ & $\mathrm{meq} / \mathrm{l}$ & $\mathrm{meq} / \mathrm{l}$ & $\mathrm{meq} / \mathrm{l}$ & $\mathrm{meq} / \mathrm{l}$ \\
\hline $\mathrm{p} 4$ & $0-35$ & 47.37 & 8.16 & 0.24 & 6.50 & 2.00 & 0.48 & 0.11 \\
\hline & $35-90$ & 42.32 & 7.94 & 0.72 & 5.00 & 2.50 & 2.13 & 0.10 \\
\hline & $90+$ & 55.79 & 8.14 & 0.56 & 7.00 & 2.00 & 1.17 & 0.10 \\
\hline Profile No. & Depth & O.C & clay & Silt & Sand & Gravel & Texture class \\
\hline & $\mathrm{cm}$ & $\%$ & $\%$ & $\%$ & $\%$ & & \multicolumn{2}{|c|}{} \\
\hline $\mathrm{p} 4$ & $0-35$ & 0.03 & 20.09 & 18.45 & 61.46 & & \multicolumn{2}{|c|}{ sandy clay loam } \\
\hline & $35-90$ & & 40.14 & 3.41 & 56.45 & & \multicolumn{2}{c|}{ sandy clay clay loam } \\
\hline
\end{tabular}


The suitability of the land to different crops is determined for field and horticultural crops (vegetables and fruits) according to Table 9.

Table 9. Land suitability to agricultural crops

\begin{tabular}{|c|c|}
\hline $\begin{array}{l}\text { Suitability index for a crop or the } \\
\text { average for a group of crops }\end{array}$ & Degree of suitability \\
\hline $0-20$ & Unsuitable \\
\hline $20-40$ & Poor \\
\hline $40-60$ & $\begin{array}{l}\text { Lytic/TypicTorriorthens } \\
\text { MODERATE: } \\
\text { Field crops: Ground nut, Haricot beans } \\
\text { Vegetable: Potato } \\
\text { Fruits Date palm,Orange } \\
\text { Litic Haplocambis } \\
\text { Fieldcrops:Horicot beans,Chick pea,Lentils,Soya } \\
\text { bean } \\
\text { Typic Halocambis } \\
\text { Field crops: Ground nuts } \\
\text { Fruits:Grape, Dade, Orange }\end{array}$ \\
\hline $60-80$ & $\begin{array}{l}\text { Torriorthens } \\
\text { GOOD: Wheat,Barley,Lentils,Alflfa } \\
\text { Vegetable: Onion,Tomato,Sweet paper,Cabbage } \\
\text { Fruits: Date palm,Orange, grapes } \\
\text { Litic Haplocambids } \\
\text { Field crops: Soya bean,Ground nut,Sorgum,Maize, } \\
\text { peas, Faba bean, Subflower } \\
\text { Vegetable:Onion Tomato, Cabbage,Potato,Sweep } \\
\text { peper. } \\
\text { Fruit: Grapes Data palms,Banana, Guava,Mango, } \\
\text { Orange } \\
\text { Typic Halocombids } \\
\text { Field } \\
\text { Soyabean,Sorgum,Maize,Peas } \\
\text { Sunflower. } \\
\text { Vegetable:Onion,Tomato, Potato,Sweet peper, } \\
\text { Cabbage } \\
\text { Fruits: Grapes }\end{array}$ \\
\hline
\end{tabular}




\section{CONCLUSIONS}

1. The level of both macro and micronutrients is low which is not unexpected of such soils that have developed under desert conditions with minimal weathering. This require an effective fertilizer program by addition of nitrogenous, phosphatic and potassic fertilizers, together with foliar spray of micro nutrient fertilizers for successful crop production. The recommended doses are: $100 \mathrm{~kg} /$ feddan urea splitted to two doses and/or ammonium sulphate at the rate of $150 \mathrm{~kg} / \mathrm{feddan}$ applied once and $100 \mathrm{~kg}$ super phosphate per feddan before planting every other season.

2. The organic carbon, and hence, organic matter is low as expected. Therefore, addition of organic manures should be entertained. Fresh organic manures (farmyard manure) could be applied at the rate of three to $5 \mathrm{~T} /$ feddan and chicken manure at the rate of $2 \mathrm{~T} /$ feddan. Green manure is also beneficial.

3. The infiltration rates of some soils are either high or low. This fact coupled with the undulated topography of the area, might suggest that modern irrigation systems e.g. drip, sprinkler, center pivot...etc. should rather be adopted.

4. Three Soil Groups have been identified; Lytic/Typic Torriorhens, Litic Haplocamids and Typic Haplocamids.

\section{LITERATURE}

[1] FAO (1976). A frame work for land evaluation. Soil Bulletin 32, Soil resources development and conservation services, Land and Water Development Division (AGLS), FAO HQ. Rome.

[2] FAO (1985) Guidelines: Land evaluation for irrigated agriculture. Soils Bulletin 55. FAO, Rome 231p.

[3] Geological map of the Sudan (1981). Geological and Mineral Resources Department, Sudan.

[4] FAO (1973). Drainage of Salty Soils. Paper No 16, Rome.

[5] Soil Survey Staff (2003). Keys to Soil Taxonomy. United States Department of Agriculture, Natural Resources Conservation Service, Ninth Edition, 2003, Washington D.C., USA.

[6] Boul, S.Et all. (1973). Soil genesis and Classification, the Iowa State Univers. Press. Ames.,

[7] Allison, L.E. (1956). Soil and plant responses to VAMA and HPAN soil conditioners in the presence of high exchangeable sodium, Soil. Sci.of Amer.proceed. vol.20, No.2.

[8] Van der Kevie, W. and O. A. M. El-Tom (2003). Manual for Land Suitability Classification for Agriculture with Particular Reference to Sudan. Ministry of Science and Technology, Agric. Research and Technology Corporation. Land and Water Research Center, Wad-Medani, Sudan.

[9] Christiansen, J.E. (1947). Some permeability Characteristics of Saline and Alkali Soils. Agr.Eng., Vol.20. 


\title{
ISTRAŽIVANJE POGODNOSTI ZEMLJŠTA I BILJNIH VRSTA, KAO OSNOVE ZA IZBOR OPTIMALNE STRUKTURE I MODELA ROTACIJE USEVA, SA PRIMENOM NA DUBOKA REZIDUALNA ZEMLJIŠTA REGIONA DONOGOLA (SEVERNI SUDAN-DONGOL)
}

\author{
Žeželj Branislav ${ }^{1}$, Hojka Zdravko ${ }^{2}$ \\ ${ }^{1}$ Megatrend, Fakultet za Biofarming, M. Tita 39, 24300 Bačka Topola, Srbija \\ 2“Meling” DOO, Marsala Tolbuhina 13, 11080, Belgrade-Zemun, Srbija \\ e-mail: melingzezelj@gmail.com
}

\section{REZIME}

Cilj studije je istraživanje pogodnosti zemljišta za organizaovanje poljoprivrene proizvodnje, te modela korišćenja zemljišta, što je delom opisano od FAO (1976), kao i utvrđivanje specifične pogodnosti zemljišta za specifične načine njegovog korišćenja u sisitemu integrisane poljoprivredne proizvodnje i sisitema savremenog menadženta, što je upotpunjeno rezultatima predmetnih istraživanja.

Utvrđena su dva specifična premeta-cilja:

I. Ispitiv anje karakteristika zemljišta i klasifikacija istih prema (USA Soil Lab.),

Taksonomija zemljišta (Profili i rutinske observacije u Excel) - kartiranje (scl. 1:25,000).

III. Evaluacija zemlji: fizičke osobine projektne zone u uslovima navodnjavanja, prema Sys et. al. (1991) za određeni broj odabranih biljnih vrsta, uobičajeno u setvenoj strukturi u okolnoj regiji.

Dobijeni poljski i laboratorijski rezultati istraživanja su utvrdili postojanje 3 grupe zemljišta (Tipic/Litic Torriorthens, Litic Haplocamids and Typic Haplocamids), te je izvršena detaljna evaluacija istih, sa ciljemutvrđivanja naj adekvatnijeg modela setvene strukture i rotacije useva na površinama zemljišta Severnog Sudana, bazirano na "optimizaciji uslova i pogodnosti zemljišta i biljnih vrsta".

Korišćenjem ovog modela izvršena je detaljna evaluacija različitih Ratarskih, Povrtarskih I Voćarski kultura, te izvršen finalni izbor i prezentacija korišćenja osnovnogdetaljnog modela sprovođenja I vođenja biljne proizvodnje, u okviru celovitog programa održive i integrisane poljoprivredne proizvodnje područja.

Ključne reči: Evaluacija zemljišta, reklamacija zemljišta, pogodnost zemljišta, rezidualna zemljišta, ispiranje soli.

Primljeno: 10. 12. 2019. god.

Prihvaćeno: 17. 12. 2019. god. 